\title{
Practicalities of implementing open pedagogy in higher education
}

\author{
Michael Paskevicius ${ }^{*}$ (D) and Valerie Irvine
}

\author{
* Correspondence: mpaskevi@uvic. \\ University of Victoria, 3800 Finnerty \\ Rd, Victoria, BC V8P 5C2, Canada
}

\begin{abstract}
This paper presents findings from a study which explored the ways in which postsecondary educators in British Columbia are reforming their teaching and learning practice as result of open education. Using a phenomenological approach with selfidentifying open education practitioners we explore how openness is being enacted through learning design. Structuration theory is used as a theoretical lens to explore innovations to pedagogy through three modalities, which include facilities, norms, and interpretive schemes. The analysis identifies how participants in this study draw upon these modalities to support openness in their teaching. The findings suggest that open educational resources and practices can support learner-centered educational designs and should be considered design technologies, those that have the capacity to enhance teaching and learning practice; rather than simply content delivery technologies, those that influence the cost and access to education.
\end{abstract}

Keywords: Open educational practices, Open pedagogy, Learning design, Open and networked learning, Technology integrated learning, Digital literacy

\section{Introduction}

For researchers interested in the ways in which open education is impacting teaching and learning practices of individuals, it has been suggested that "openness is the enemy of knowability" (Beetham, 2011, p. 7). This is due in part to the unseen, unreported, flexible, and unstandardized ways in which open educational resources (OER) are accessed and used (Harley, 2008; Pulker \& Calvi, 2013; Weller, de los Arcos, Farrow, Pitt, \& McAndrew, 2015). Researching the impact of openness on teaching and learning practices represent an even greater challenge, as gaining access to classrooms and digital learning environments, combined with the inherent considerations around data protection and privacy create a challenging landscape for conducting research (Weller et al., 2015). Consequently, a number of scholars have suggested more qualitative empirical research is needed to understand the phenomenon (Beetham, Falconer, McGill, \& Littlejohn, 2012; Borthwick \& Gallagher-Brett, 2014; Camilleri, Ehlers, \& Pawlowski, 2014; Littlejohn \& Hood, 2016; Pitt, 2015).

This paper builds upon a recently published paper in which faculty members describe how and why they are using open education to guide their pedagogical designs (Paskevicius \& Irvine, 2019). The purpose of this paper is to further contribute to the literature by detailing how open educators are changing their teaching and learning in a practical way. To investigate this, interviews were conducted with faculty members

(c) The Author(s). 2019 Open Access This article is distributed under the terms of the Creative Commons Attribution 4.0 International License (http://creativecommons.org/licenses/by/4.0/), which permits unrestricted use, distribution, and reproduction in any medium, provided you give appropriate credit to the original author(s) and the source, provide a link to the Creative Commons license, and indicate if changes were made. 
in British Columbia, who describe changing their pedagogical approaches in pursuit of open education. We begin with a review of related literature, present the study's research questions and methods, then present the results and provide a discussion of the findings.

\section{Relevant literature}

The terms open pedagogy, open educational practices, open teaching, or open practices are often used interchangeably and have been defined as "the next phase in OER development, which will see a shift from a focus on resources to a focus on OEP being a combination of open resources use and open learning architectures to transform learning" (Camilleri \& Ehlers, 2011, p. 6). Open educational practices (OEP) have been defined as those teaching and learning practices enabled and supported by the open movement, either in making use of OER, engaging learners with the practices associated with open education, creating opportunities for learners to engage openly themselves, or making our professional practice more accessible. The Cape Town Open Education Declaration (2007), one of the founding documents on open education, suggests a broad vision which goes well beyond the proliferation of openly licensed educational content:

open education is not limited to just open educational resources. It also draws upon open technologies that facilitate collaborative, flexible learning and the open sharing of teaching practices that empower educators to benefit from the best ideas of their colleagues. It may also grow to include new approaches to assessment, accreditation and collaborative learning (para. 4)

Scholars have argued that research on openness in education should focus less on access and use of digital content, and more so on the impact of openness in supporting innovative educational practices (Jung, Bauer, \& Heaps, 2017; Kimmons, 2016; OPAL, 2011). Among the open education community, the recent turn to interest in open pedagogy has generated an increase in discussion around how openness could support changes to teaching and learning. By exploring a broader notion of openness in education, we shift the focus to the practices that are possible when using openly licensed and adaptable content and resources (Deimann \& Farrow, 2013). The shifting focus of discourses from OER towards open practices represents an optimistic advancement of the field, as this represents a change from developing and releasing OER content and materials to researching their impact on educators' practices (Weller et al., 2015). As found with the costly learning object repository movement, educational technology initiatives should support and report on practices and processes rather than considering content in isolation from practice (Friesen, 2009).

Scholars have suggested a movement towards OEP provides an impetus for innovative teaching and learning processes, resulting in new conceptualizations of the roles and practices of both educators and learners (Lane \& McAndrew, 2010; Littlejohn \& Hood, 2016; Porter, 2013). Some scholars suggest that faculty should be encouraged to design assignments which involve learners in the creation and adaptation of OER (Jhangiani, Pitt, Hendricks, Key, \& Lalonde, 2016). Engaging learners in the production of OER levels the faculty-learner relationship by engaging learners as co-producers of 
knowledge (Masterman, 2016). In designing learning that can be shared with others, faculty are better able to view one another's learning designs and approaches, providing greater diffusion of innovation. In this way, engaging with open education has been posited to be a catalyst for pedagogical innovation in higher education, specifically for those not classically educated in pedagogy.

As previously mentioned, both researchers and practitioners have defined the impact of openness in education in various ways. In the field, the terms used to describe these practices vary, and include OEP, open educators, and open pedagogy. It would appear that OEP covers the most broad spectrum of an educators practice and may include engagement with open access research, open sharing or data, and open scholarship (Andrade et al., 2011; Banzato, 2012; Carey, Davis, Ferreras, \& Porter, 2015; Cronin, 2017; Hood \& Littlejohn, 2017; Paskevicius, 2017; Rolfe, 2017; Stagg, 2014, 2017). Open pedagogy is more focused on the impact of openness on teaching and learning practice, essentially how one engages with learners (Hegarty, 2015; Hodgkinson-Williams \& Gray, 2009; Wiley, 2017). Wiley (2017) and Wiley and Hilton III (2018) offered the term OER-enabled pedagogy, describing the activities made possible when using OER. The term open educators has also been used to describe those that take up openness in various aspects of their teaching practice (Nascimbeni \& Burgos, 2016). Others have described OEP in relation to learner activity specifically, and how it affords greater personalization, autonomy, and self-regulation on the part of learners (Ehlers, 2011; Kaatrakoski, Littlejohn, \& Hood, 2017). OEP have also been defined as teaching and learning activities where both "resources are shared by making them openly available and pedagogical practices are employed which rely on social interaction, knowledge creation, peer learning, and shared learning practices" (Ehlers, 2013, p. 94).

Despite the advancements in educational technologies, many faculty members teaching in higher education continue to operate as they did in the past (Bates et al., 2017; McGoldrick, Watts, \& Economou, 2015). However, there are educators, albeit a minority, that are beginning to use open technologies and knowledge in ways that impact their pedagogy. Some educators make shifts where their previously closed teaching environments influence their open education design. The most common example, especially now that the internet enables access to a wealth of information and knowledge ubiquitously (Yuan, MacNeill, \& Kraan, 2008), includes making use of OER as part of the curriculum, thereby facilitating more reasonable access to course materials instead of those purchased commercially from a publisher at a high cost. In contrast, others have advocated for open access to be more influential on their closed teaching environments, shifting the scope of participation of learners, experts, and community members within and beyond the classroom. For example, expanding the access of traditionally face-to-face classes to consider both synchronous and asynchronous modalities as well as open access to engage learners, which ultimately can shift the closed discourse and fundamentally expand the sphere of participation to include open learners through blogging, video conferencing, and social media (Irvine, Code, \& Richards, 2013).

Open pedagogy is so much more than adopting OER, such as open textbooks, which essentially represents a change to the resource used as part of the curriculum, while not necessary resulting in changes in pedagogy. What open pedagogy affords, in contrast to closed pedagogical approaches, is an increase in autonomy on the part of the learner, both in terms of the resources they use to support their learning and the 
software, services, and platforms they choose to create and share their works. A diversity of resources, from a variety of perspectives can be achieved by accessing knowledge and resources from a variety of perspectives and authors, as opposed to the single textbook model, which is still commonly used in many university courses. Learners may also be invited to contribute resources to enhance the discourse, creating opportunities for discussion, and promoting peer review. Additionally, open pedagogy puts greater emphasis on learners selecting the service and platforms they use to share their creative works, allowing these to be presented in the form and format they choose, leveraging the open internet to showcase and gather feedback on the work. Again this differs from the traditional centralized approach, where learners' creations are stored in a platform directed by the faculty member, most commonly a learning management system, a toolset characterized by its closed, rigid, over functioned, and inflexible nature (van Mourik Broekman, Hall, Byfield, Hides, \& Worthington, 2014). The physical and digital boundaries created by these environments often determine the available pedagogies and control access (Dron, 2016; Lane, 2009). An open pedagogical approach should allow learners to have more control of their digital works and be able to take them with them as they leave formal education.

\section{Theoretical framework}

The phenomenon associated with open education remain under-theorized in the literature, which represents both a challenge and opportunity for further research (Bulfin, Henderson, \& Johnson, 2013; Howard \& Maton, 2011; Knox, 2013; Veletsianos, 2015). There exists an opportunity to develop new theory, as well as to connect the phenomenon associated with open education to existing theory from education, learning sciences, and pedagogical research. Much of the literature has focused on case studies, strategies for implementation, and broad approaches to institutional change which do not draw upon or develop theory. A significant amount of the empirical work reviewed makes no mention of a theoretical base (Beaven, 2013; De Los Arcos, Farrow, Perryman, Pitt, \& Weller, 2014; Jhangiani et al., 2016; Masterman, 2016; Masterman \& Wild, 2011; Petrides, Jimes, Middleton-Detzner, Walling, \& Weiss, 2011; Pitt, 2015). Further, critical studies which examine the pedagogical and educational implications of the use of OER and engagement in OEP are even less common (Knox, 2013). Empirical studies which attempt to develop theory include those using communities of practice (Harris \& Higgison, 2003; Koohang \& Harman, 2007; Tosato \& Bodi, 2011), activity theory (Alevizou, 2012; Paskevicius, 2011; Paskevicius \& Hodgkinson-Williams, 2018; Porter, 2013), and more recently social realist theory to investigate engagement in OEP (Cox, 2016; Cronin, 2016).

In the present study, structuration theory is used as a lens for the analysis, which emphasises how technology usage is both under the influence of, and at the same time contributing to, the shaping of the social practices in an organizational setting (Halperin, 2016; Orlikowski, 2000). The theory offers a useful heuristic by framing the role of individuals as being actively involved in the enactment of social practices which constitute and replicate structure over time. Social structures are therefore reproduced through human activity, while at the same time structuring and informing activity. Individuals apply their knowledge, available tools, facilities, and habits to structure their current action and in doing so, recursively instantiate and thus reconstitute the rules 
and resources that structure future social action (Orlikowski, 2000). Structured social practices are institutionalized or normalized when they become routinized over time and acknowledged as commonplace (Giddens \& Dallmayr, 1982). However, a key component of the theory is that "the seed of change is there in every act which constitutes towards the reproduction of an 'ordered' form of social life" (Giddens, 1993, p. 108). As such, individuals always have the option to enact new practices in their activities defying structural perceptions and enacting innovation. Structuration theory defines the structural elements of social systems as a set of modalities which form resources mediating social activity which include: interpretive schemes, drawing on a subjects' knowledge, beliefs, and assumptions about learning as well as their perceptions of technology in aiding learning (Halperin, 2016); facilities, including technology, land, or infrastructure being employed; and norms, which include the common practices, protocols, and etiquette common for the social context (Aktaruzzaman \& Plunkett, 2016). A visual model of the theory, situated in the content of OEP, is presented in Fig. 1.

The Clark versus Kozma debate on educational media was also used to frame this study. Clark (1994) delineated between 'delivery technologies,' those that influence the cost and access to education, and 'design technologies,' which include the practices and environments that enhance learning. He argued that the instructional strategy was far more significant than the type of medium being used. OER may be considered 'delivery technologies' which impact the cost and ways in which we access knowledge. Kozma (1994) argued that rather than exploring how, or if, different forms of educational media impact learning, we investigate the ways in which we can use the capabilities and affordances of specific media to influence learning. The debate is helpful when scrutinizing innovation in the context of OER use. If no changes to pedagogy occur when OER is used, OER simply represents a new form of 'delivery technology' rather than one that has the potential to impact the design of learning experiences. Clark argued that where no significant difference exists in the learning outcomes between two forms of media, the least expensive solution is the obvious choice (Clark, 1994). It seems fairly obvious that both faculty and learners would choose an accessible and

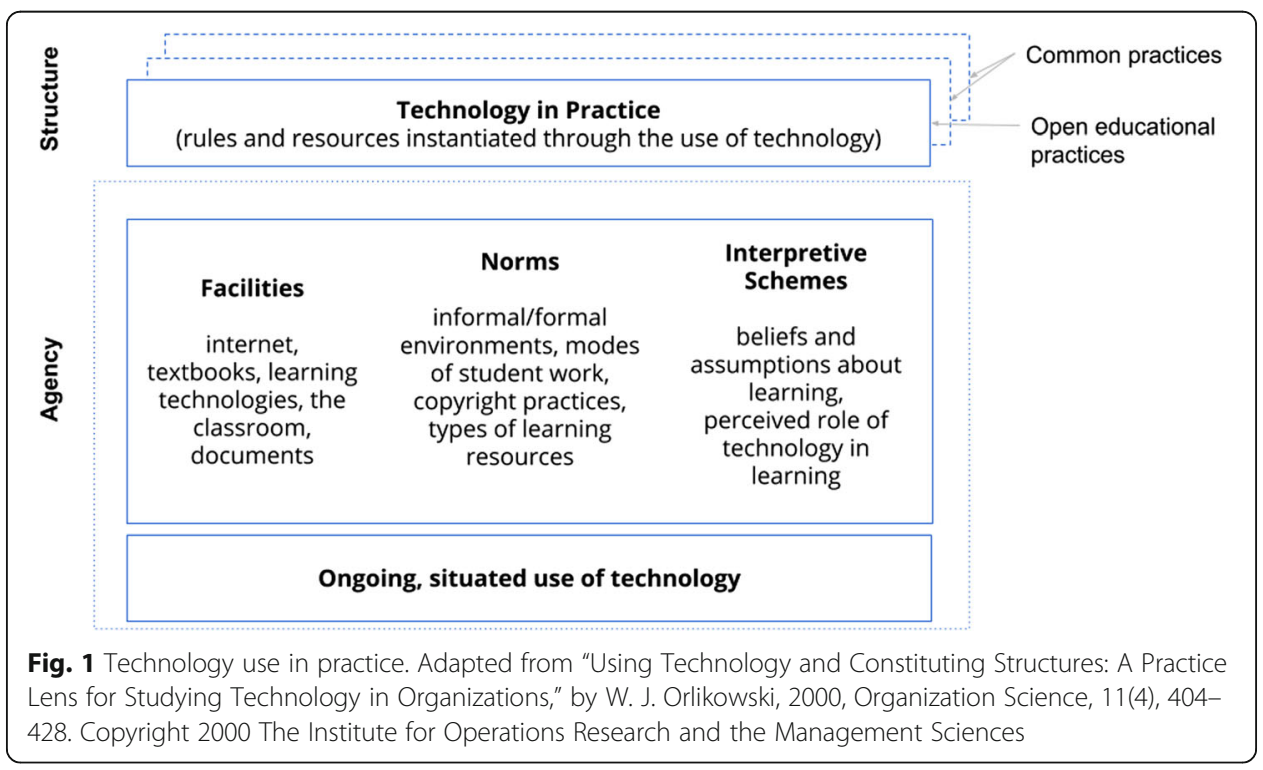


affordable text over an expensive one, where no significant difference exists in the quality of these resources. In this study, we therefore investigate changes to design enacted through OEP.

\section{Methods}

For the purposes of this study, the term OEP was used in framing the research questions, engaging with participants, and in the presentation of the research. Ultimately, the goal of the research was to investigate how faculty are bringing aspects of openness into their practice, through their pedagogical designs, and in how they talk about using OEP to engage with students. A qualitative approach is used to capture the experiences of participants, to better understand meaning formation through and as part of culture, and to discover themes among this population through a process of discovery (Corbin \& Strauss, 2008). An empirical phenomenological approach is used to investigate the personal social construction and 'lifeworld' human experience of individuals engaging with OEP (Giorgi, 1997; Gray, 2014). This research was subjected to ethical review by the British Columbia (BC) Ethics Harmonization Initiative and was approved prior to data collection.

In this study, we investigate the lived experiences of 11 educators who describe actively changing their pedagogical practice due to their engagement with open education. Participants were purposefully selected based on their situational ability to reflect on their experiences relating to their engagement with OEP (Creswell, 2012; Horsburgh, 2003; Kruger, 1988). All but two participants were working at research-intensive universities in B.C., six of the participants were working in research-focused faculty positions, while five maintained teaching-focused roles. Details of the participants in the study are presented in Table 1 .

Participants were interviewed using synchronous video through the Zoom online meeting service. The interviews lasted on average for $1 \mathrm{~h}$ and were audio recorded for transcription and analysis. Participation in the research was voluntary and participants were informed that they could withdraw from the study at any time. Interview transcripts were imported into NVivo for qualitative analysis. A full reading of all the transcripts was conducted twice, initially for a holistic analysis, then to begin thematic analysis. A structured analytical approach guided the analysis of phenomenological

Table 1 Summary of interview participants

\begin{tabular}{|c|c|c|c|}
\hline Name & Age range & Faculty & Job title \\
\hline Katherine & $50-49$ & Forestry / Land and Food Systems & Assoc. Prof. \\
\hline James & $30-39$ & Education & Professor \\
\hline Patricia & $20-29$ & Humanities & Ph.D. Candidate \\
\hline Robert & $30-39$ & Arts & Instructor \\
\hline Alice & $40-49$ & Arts & Professor \\
\hline Margaret & $40-49$ & Social and Applied Sciences & Assoc. Prof. \\
\hline Joanne & $40-49$ & Environment & Ph.D. Candidate \\
\hline Olivia & $30-39$ & Communication, Art, and Technology & Assist. Prof. \\
\hline Thomas & $30-39$ & Communication, Art, and Technology & Professor \\
\hline William & $40-49$ & Science and Management & Assoc. Prof. \\
\hline Tracy & $60-69$ & Social Sciences & Professor \\
\hline
\end{tabular}


data, first through a process of bracketing in which the beliefs and assumptions of the researcher are articulated through rigorous self-reflection (Creswell, 2013; Hein \& Austin, 2001). Giorgi (1997) describes this as seeking to freshly encounter the phenomenon, describing it precisely as experienced and described by the individual.

\section{Results}

Many of the OEP learning designs represented in this study draw upon existing strategies for learning design, including social-constructivism, peer-review, inquiry driven assessment, and ongoing formative feedback. For those with extensive experience researching education theory, learning design, or pedagogy, these practices may not resonate as new and emerging. However, the availability of new and emerging technologies provides refined tools for enacting these principles in learning design, and providing opportunities for faculty to change their practices, employing principles of sound learning design, under the guise of OEP. This may lead to new norms and interpretations of how we design learning and conduct teaching and learning in higher education.

\section{Facilities supporting OEP}

Faculty in higher education have a myriad of technologies available to use in their practice. Most commonly, the LMS is the default tool for engaging with learners and facilitating learning in higher education, but increasingly more open technology tools are becoming available as well. Many faculty gravitate towards using the LMS as a consequence of its availability (Bennett, Dawson, Bearman, Molloy, \& Boud, 2016). However, an increasing number of tools exist online which can be taken up in the practice of teaching and learning (Bower, 2016). The way that faculty make use of these tools in the practice of teaching and learning can be driven by various motives. Faculty in this study largely describe being driven by a spirit of openness, which guided their use of technologies in practice. They described doing so for several reasons; to promote access to knowledge, to engage with communities, and to get learners critically engaging with public knowledge. In order to be successful in achieving these goals, educators require an understanding of the affordances of emerging open tools, digital and network literacies, as well as pedagogical knowledge for enacting open education.

Throughout the study, participants described how they were making use of technology to support their engagement with OEP. Their approaches to using technology were largely nascent and not necessarily a consequence of the technologies inherent design. Participants were motivated by a variety of factors which prompted their use of technology to achieve those goals. From a structuration standpoint, participants appropriated some of the structures presented in available educational technologies in order to enact OEP (Orlikowski, 2000). This enactment relies upon their understanding of the perceived rules and available resources shaped by their pre-existing knowledge and past engagements with these technologies. Through regularised practice, their perceptions of the interpretive schemes, rules, and facilities iteratively structured their ongoing interaction with the technology (Halperin, 2016). This study has revealed some of the situational and local factors supporting the learning design strategies of faculty using educational technologies to support OEP. 
The emergent learning designs described in this study are both under the influence of, and contributing to, the shaping of teaching and learning practices in higher education. Through in-use design, where innovators experiment with new learning designs and approaches, they concurrently contribute to reshaping and establishing new approaches to using technology in teaching and learning. (Halperin, 2016). The structuration practice lens approach suggests that: "rather than starting with the technology and examining how actors appropriate its embodied structures, this view starts with human action and examines how it enacts emergent structures through recurrent interaction with the technology at hand" (Orlikowski, 2000, p. 407). Open technologies including content, software, and licenses afford individuals greater possibilities for action. As these open technologies are characterized as networked, modular, reusable, shareable, and remixable, they afford designers a highly flexible and open-ended quality, amenable to a wide variety of uses and adaptations over time. One additional advantage of working more openly involves the adoption of open standards, allowing a learner more options to export both the literacies gained in using open technologies, as well as being able to take their work with them for personal pursuits.

Inherently, the use of technology by faculty for teaching and learning can be considered a shared practice. That fact that most educational technologies are selected, administered, and directed individually by the faculty member does not change their shared nature (Halperin, 2016). Whether learners work within a physically shared software system, such as a multi-author publishing platform; or are tasked with creating individual domains or reflective writing spaces, they still operate within a collective at least for the duration of the course. Various collaborative software tools were instrumental in mediating these experiences, including Wordpress, Open Journal Systems, Hypothes.is, Google Docs, and even the LMS, which was often used for coordinating, planning, and preparing for an OEP learning design. The various combinations and configurations for using these tools were selected by the faculty member based on their availability and appropriateness to support the design. Additionally, various creative software tools were important to support flexible forms of digital media. These included video authoring and editing tools, software for creating podcasts, portfolios, digital editions, textbooks, or other ancillary resources.

As participants reflected on their experience engaging learners with openness, a distinction emerged between the ways we might engage with more open practices as part of learning design. This distinction is drawn between how we consider openness in terms of the ways in which we source materials for our own designs, how we compile and build our own resources, and how we use open tools and resources as a means of communicating and sharing more openly. This seems to imply at least three distinct approaches to openness around pedagogy: the exploration of open resources, explicitly building openness into the process of designing learning resources and artefacts, and openness as an approach to publishing. These three types of openness are not mutually exclusive and may be combined as part of a learning activity. The three categories of openness are represented in Fig. 2.

Throughout the research, these three types of openness did not necessarily transpire together, as participants brought aspects of these approaches into their teaching and learning in various ways. We found synergies with the idea of parsing out specific components of openness in Clark's dichotomy between design and delivery technologies 


\begin{tabular}{|r|r|}
$\begin{array}{r}\text { Exploring open } \\
\text { resources }\end{array}$ & $\begin{array}{l}\text { - Bringing awareness to the availability of OER, } \\
\text { open copyright licenses, online repositories, } \\
\text { and techniques and strategies for locating OER }\end{array}$ \\
Openness by \\
design \\
$\begin{array}{r}\text { Open online } \\
\text { publishing }\end{array}$
\end{tabular}$\left\{\begin{array}{l}\begin{array}{l}\text { Engaging with the tools, resources, and } \\
\text { practices for creating new artefacts which could } \\
\text { be shared openly as OER }\end{array} \\
\begin{array}{l}\text { - Publishing artefacts, online reflections, } \\
\text { engaging in peer-review, and presenting } \\
\text { resources as OER on the open web }\end{array} \\
\hline\end{array}\right.$

(Clark, 1991, 1994). It may be helpful for practitioners to consider openness in learning design by considering how it impacts design and delivery independently, while recognizing that increasingly, these are merging within popular digital and social media technologies.

The first category, exploring open resources, involves bringing awareness to learners about the availability of OER, open copyright licenses, online repositories, and techniques and strategies for locating OER. Additionally, as represented in two of the learning designs described in this study, this provides an opportunity to critically assess the source of materials, investigate authorship, and vested interest. Working with OER as source material also provides an opportunity for individuals to practice working with digital media; selecting, copying, editing, adapting, and remixing materials as needed to construct their own works. This represents an analysis task, which necessarily precedes a design task, requiring learners to engage closely with open sources of information, make decisions about how they scrutinize, compile, and present information, and consider how they could build new knowledge resources. It is important that learners recognize that they are working with OER and have an understanding of what that makes possible under an open license. This may require faculty to be explicit to learners when they are using OER as a knowledge resource, drawing attention to open licenses, and making clear the possibilities for repurposing the resource because of the affordances provided through the open license.

The second category, openness by design, involves engaging with the tools, resources, and practices for creating resources that can be legally shared openly. This is done by using legally reusable source material, properly attributing content creators, and designing resources in open formats. These resources may or may not be shared in the end, but they are created in a way that would allow them to be shared openly once complete. Furthermore, these resources may be initially shared locally, on a user's hard drive, or within a closed learning environment; they may not be developed in the open. Openness by design implies a set of tools, techniques, and literacies for the design of digital media which can be shared openly. The author of the resource makes an informed choice if they wish to share their work more widely by moving on to open publishing. Should they make the decision to share their work, the resource will have been designed in a way that it can then be openly shared. Should they decide not to share, the resource may remain offline or in a password protected environment but still technically could be revised by another individual. 
The third approach involves individuals publishing their reflections, engaging in peer review, and contributing resources more broadly on the open web. In some cases, this is done not by creating standalone resources that might be considered OER, but rather in the form of reflective practice, blogging, or journaling. This may be motivated by the opportunity to share learners' work more widely, invite peer review, or engage the community. Additionally, open publishing could be used as a way to share the creations developed through the exploration of open resources or openness by design. In this way, open publishing can take on many forms, from reflective blogs to collections of resources. Open publishing requires more explicit attention to what is being shared, to avoid the oversharing of personal or identifiable information. Using Clark's (1994) terminology, this may be considered a delivery technology, which is enhanced by realtime access, formative peer or instructor evaluation, and community engagement. Increasingly, learners can design resources within delivery technologies, for example creating and combining resources together on a website. Alternatively, the website may be used as a means to deliver a resource, which may have been authored in another program, for presentation on the web.

For several participants, the goal for using OEP learning designs was the development of resources which could be shared in the open, in other cases the goal was to locate, scrutinize, and review open resources. Analysis and review of OER could precede an activity where learners are tasked with adapting or building upon the resources they have found. In a third case, learners were tasked with starting directly with open publishing, often in the forms of reflective blogs or portfolios.

If the starting point is to assess and review OER or build resources which could be shared as such, much of the development work can happen in private, allowing learners to work incrementally towards openness, perhaps first working in a private space, then making their work more available for review. Learners must be skilled in the open literacies which enable them to build digital media that could be shared openly if they choose to do so. So, it is possible to have learners working within a closed environment to develop open resources. This is different to what is most commonly happening today, where learners are developing resources within closed learning environments without consideration for copyright or open sharing. These resources can end up being both legally and technically impossible to share, while trapped within a closed learning environment. Furthermore, learners may lose access to the resources they have created, the discussions they have contributed to, and other artefacts of their learning which are removed from the LMS as their courses end.

Where learners are tasked with open publishing, they are often invited to work in the open from the beginning. Again, open and network literacies are crucial for learners to work appropriately in this way. It is possible for learners to source or use copyright resources on an open platform, which could constitute a copyright violation. Learners also need an awareness of how to share digital media openly while using appropriate formats so that others can make use of their work, if that was the intent. Some of the permeations represented through this parsing out of openness are represented in Fig. 3.

Figure 3 displays common ways in which learners create and distribute learning artefacts and resources through the OEP learning designs represented in this study. Faculty largely encouraged learners to create resources, designed in a way that could be openly 


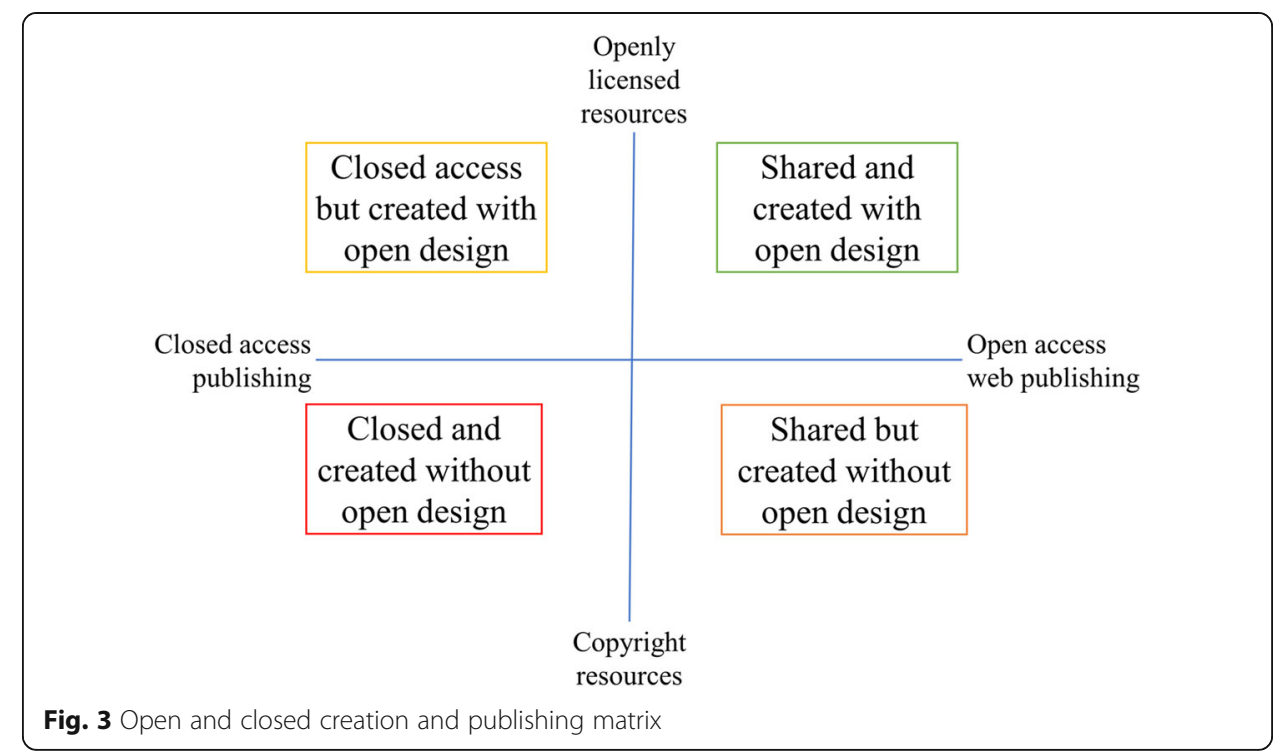

shared. These may be developed by learners while not being shared openly, either on the learner's local machine or within a password protected environment. This is represented in the upper left quadrant, and required learners to source material with open copyright, appropriately cite sources, and use web-ready open formats. These resources, while not necessarily shared immediately, have the potential to be shared at any time at the learners' discretion, represented in the upper right quadrant. An alternative approach represented in the lower left quadrant, is in designing learning artefacts and resources which do not use OEP as a design approach. These works may include copyright restricted materials or other source materials that could make them inappropriate for sharing openly. Learners may very well choose to share these works openly, but in doing so they may be violating copyright or exhibiting improper practice by doing so.

In addition to open technologies being widely available at their institutions, many faculty members reflected on the other facilities used to support their work engaging with OEP. These included grants, which allowed them to focus time and money towards changing their pedagogical practices. When grants, specifically aimed at supporting pedagogical innovation, are made available, faculty can use these to make change, reflect on that experience, and share the innovation more widely at their institution or among their colleagues. Not all cases studied required grant funding, and many had engaged with pedagogical innovation without additional resources. Partnerships at the university can also be integral to supporting change. Olivia reflected on her experience working in partnership with colleagues:

I would not be doing any open pedagogy of any kind if other members of the university community hadn't invited me to do so. Which is to say that, like, it came from community service learning at the [institution], and it comes from the library here, and it's almost entirely been driven by, sort of, invitations to experiment, or invitations to collaborate that came from those people. And that is in part because I don't know if I would have known those resources existed otherwise but also 
because it is too much work to take on as a single person to, sort of, reinvent the wheel. I think those partnerships have been really, really, key.

Both the library and teaching and learning support centres were frequently cited as helpful facilities supporting innovation. Partnerships with individuals who work in service departments such as the library or teaching and learning centre, allow faculty to get support and guidance from individuals who bring expertise from across campus.

Another support cited which may be relevant to supporting OEP, is that of the community outreach office, responsible for supporting student work that is embedded in the community or through partnership with industry. These offices can be integral to coordinating student work in the community, ensuring it meets community needs, is conducted with the appropriate community partners, and has the required support. Community outreach centres can support OEP, potentially supporting greater impact in the community, by forging connections between community partners and learners, ensuring the work they do meets a community need. Many of the participants in this study had made connections between OEP and community engagement, however, not all had coordinated with a community outreach centre at their institution. For some, the connection between OEP and community engagement was not entirely clear, as Alice reflected:

What about community-based learning? Is this an open practice because in some sense you're opening the doors of the classroom? Right? You're connecting with people outside. And the way that we had discussed open practices as connecting, it sounded like it was. So, then that might involve if you define that as an open practice that might involve a lot more people because there's a lot of community-based learning, or community-engaged learning. I don't know if you think, you know, community connections count as open practice, but it's just something that came to us as a colleague and I were talking recently.

Community-engaged learning can be considered a significant component of OEP, further enhanced by the deliberate capturing, curating, and sharing of those activities more widely. This can be useful for displaying and promoting the work learners do in the community, while also providing a resource for future learners to sustain community engagement activities. By detailing and sharing their activities, future learners can develop further those community engagement activities, rather than starting from scratch. Olivia commented on the challenge in trying to coordinate these relationships alone, especially if each learner has a different community partner, "I would have to be tracking down those organizations, communicating with them, convincing them to work with the university, facilitating the relationship." OEP initiatives which impact community partnerships may require additional support to ensure the results are incremental and deemed positive for the learners, faculty, and community.

\section{Norms supporting OEP}

Faculty members in higher education have are faced with several routine and normalized modes and methods for conducting teaching in learning. Several of these norms were challenged as they engaged with OEP. Firstly, participants in this study described 
the importance of building in new digital literacies required to create open resources and use networks appropriately as part of the curriculum. These emergent open and network literacies may be established as new norms and expectations for learners in the information age, and have been referenced as motivators for OEP by previous researchers (Cronin, 2017; Kimmons, 2016; Masterman, 2016; Masterman \& Wild, 2011). However, as evidenced in the literature and reflected in this study, these open and network literacies are not often well established in learners, even as they enter higher education. How will learners develop open and network literacies if we only engage them in using the LMS, an environment that they may never use again in their professional lives? In each case of this study, learners were tasked with using tools and technologies they could take with them or use independently outside of formal higher education. In the process of using these tools and technologies, learners practiced and developed transferable open and networked literacies.

It is essential that learners have an opportunity to develop and practice open and network literacies to be successful in OEP initiatives. These literacies include knowing what and what not to share, for example personal or sensitive information when working in publically accessible digital spaces. An example provided in the study was a case of a learner oversharing personal information, which demonstrates that learners may not always recognize the implications and potential reach of their personal information when sharing openly. Further, an understanding of the norms of what is appropriate to share, how to engage with an open audience, and how to respond to queries and challenges, are essential for learners being tasked with OEP. These represent emergent literacies for working in the information age. OEP embedded as part of the curriculum provides an opportunity to explore and interrogate open and networked literacies while enabling learners to consider their own philosophy for engaging in this way. This will better prepare learners to contribute to public knowledge in the future by providing them with a chance to experience open publishing in a safe environment.

An additional norm that was challenged involved keeping copies of student work created as part of a course. Universities are often required to keep copies of learner work for at least 1 year following the conclusion of a course. This ensures that learners have an opportunity to appeal a grade received, or access work they submitted within a reasonable timeframe. In many cases, OEP assignments put the ownership of data under the learner's control. If, for instance, learners are creating a portfolio or online resource, they may be the only one with a login to the service they are using. This means that learners may take their work offline, or alter it, after it has been assessed. This could complicate the appeals process, as the work originally assessed may have evolved or changed at the time of appeal. While this issue did not emerge in the interviews, it certainly is something faculty should consider when designing OEP assessments. The risk may be mitigated in keeping a copy of student work, captured by faculty at the time of assessment. This may be done by taking a screenshot, printing, or saving a PDF copy of a web resource. Another approach is to aggregate content from the learner's online resource at the time of assessment, thereby capturing a static copy of the work at the time of import. This issue becomes more challenging when assessing online streaming multimedia, which may be technically challenging to save offline or copy.

If OEP learning designs do become a norm in higher education, a thoughtful approach should be taken. Considering OEP more strategically at the program level can 
help to ensure learners are being engaged with openness in a way that is timed, framed, and sequenced in an appropriate way. One can imagine that tasking learners with multiple concurrent open assignments could be onerous. Further, if learners are asked to set up reflective spaces for multiple courses, should they be able to use a single portfolio to do so, or would they be required to set up a separate reflective space for each assignment or course? From the learner's perspective, it makes sense to keep all of their open artefacts in a single location, but it can be challenging for faculty to accommodate environments unlike those used by the majority of the class. Challenges such as this suggest a need for a considered and more macro approach when considering engaging learners with OEP.

\section{Interpretive schemes supporting OEP}

Participants were asked about how they believed their engagement with OEP aligned with the mission and vision of the university. Olivia cited her university's branding "as the engaged university, I think it's one of the primary goals of this institution to be community engaged. So, I think experimental and public pedagogy in particular align very well." James felt his work with OEP aligned well with the academic plan and the intended institutional graduate outcomes "it's embodying what the university wants to provide and through the graduate attributes: lifelong learning, civic engagement, intellectual and practical skills come into play. And I think open pedagogy can facilitate many, many, many of those." Similarly, Margaret echoed that it is "critical is to be able to find those larger documents, the sustainability plan, your academic plan, and where can you see a direct correlation between what they're asking for and a belief of value that comes with open practices." This suggests that while OEP may be a means to achieving some of the institutional goals outlined in university mission and vision documents, the linkages between rhetoric and practice still need to be further explored. Joanne commented in a similar way, reflecting on her institutional mission and vision, "I don't know how much it's been put in practice." This suggests a need for greater clarity around how specifically faculty can enact the principles found within mission and vision statements in their everyday teaching and learning practices. While Masterman and Chan (2015) argued that openness should be explicitly incorporated into the educational mission of the university, we argue that aspects of openness are already in place in many of these documents. OEP may serve some of the most common visions for our institutions, including open access to knowledge, collaborative learning, and community engagement.

Conversely, participants reflected on how challenging and unfamiliar it can be for learners when creating and sharing their academic work online. Aligned with the recommendations of Wiley and Hilton III (2018), learners should not be required to share openly or license their works using open licenses. Rather, we can invite learners to share their works and provide them with the tools and literacies to do so appropriately. The key word there is invite; openness is an invitation to participate and share knowledge resources more widely. The work that learners share ultimately becomes part of their own digital footprint, and how that footprint takes shape should be considered. Where learners are sharing prior to peer or faculty review, there can be opportunity for negative exposure, where a resource is still in progress or unrefined at the time of 
sharing. Recognizing that learners may be taking upwards of six courses, working parttime, struggling to keep up with assignments, they risk degrading their own digital footprint when also asked to share openly. Furthermore, depending on where and how that artifact is shared may make it more challenging for a learner to unpublish or add more context to work. We should also recognize that our learners may come with sensitivities regarding privacy, where they might need or wish to remain anonymous online. Having realistic conversations with learners about how they might manage their digital footprint is another open and network literacy that several participants sought to address by discussing topics such as digital identity and online presence as part of the curriculum. Alternatively, learners should be made aware that it is possible to share openly while at the same time remaining anonymous or limiting access to specific individuals. This can be done through the use of pseudonyms or by using unlisted links to online resources. As Thomas suggested, "they send me the URL so that their identity can remain private, but their work can remain public." So, while it is possible for learners to share openly, yet anonymously, we may need to offer learners guidance on making that choice and technical help in making it possible.

For faculty, openness as an approach to design has broadened access to resources and presented opportunity for sharing their own pedagogical practices, as more faculty share the resources they create, the way they use these resources to support learning, their best facilitation techniques, or examples of student work shared openly. Openness in practice has created channels for the sharing of pedagogical practice, an opportunity for those seeking inspiration, and ultimately, appears to have led to increasing discourses around teaching and learning on a broader scale. William comments on how being more open has created opportunity for collaboration and the sharing of practice:

I don't know what happens [ ... ] in my next door office neighbour's courses specifically unless I ask and even then I don't know how that necessarily integrates with what I'm doing. So I mean universities are funny that way $[. .$.$] different$ instructors really have no clue what's happening in the next door classroom.

Openness enacted through practice presents an opportunity for enhanced sharing among colleagues, within and beyond their own department and institution. This can support professional development, networking among colleagues, and foster communities of practice among faculty.

\section{Discussion of the findings}

Supporting the findings of McAndrew, Scanlon, and Clow (2010) as well as Petrides, Jimes, and Middleton-Detzner (2010), the present study found educators using openness as an agent of change and innovation. It seems evident that openness may provide a stimulus to engage in innovative forms of pedagogy, either through having greater access to one another's' practice or through the availability and affordances of emerging tools and technologies. Based on the findings of this study, openness in practice may be framed as one approach to promote technology-enhanced teaching and learning, precipitated on the values of openness rather than specific technologies. This reiterates the need to develop greater awareness of the pedagogical affordances of designing learning using OER, open tools, and open licenses (Masterman \& Chan, 2015). 
The innovative pedagogies articulated in this study include: the exploration of open resources made possible through the explicit use, review, and analysis of OER; engaging learners with openness by design by creating knowledge resources from openly licensed works; and the open online publishing of these works for presentation and peer review. These three approaches to OER are presented in Fig. 4.

Each of these approaches to engaging with OEP require a set of prerequisite literacies and considerations for faculty members and learning designers. In Fig. 4 we have provided examples of these considerations and pedagogical approaches documented for each as found throughout the study. As previously mentioned, these approaches are not mutually exclusive and may be combined or sequenced throughout a course. We contend that the three approaches do provide several options for faculty members considering integrating OEP in their pedagogical repertoire and draw attention to the additional factors to consider.

While the issue of finding the time to engage with OEP has been raised several times in the literature (Allen \& Seaman, 2016; De Los Arcos et al., 2014; Kimmons, 2016; Petrides et al., 2011), this study contributes a more explicit understanding of the ways in which educators described using limited time and resources, and leveraging institutional structures, to engage with OEP. Time and resources are important to consider when considering OEP learning designs, specifically with larger classes, and faculty need to proactively address learner concerns, develop literacies, and support learners while engaging openly.

If OEP learning designs continue to be taken up by faculty in higher education, it would be prudent to consider the frequency and timing in which they take place within an academic program. Taking a holistic lens, and considering the student experience throughout their academic career, OEP activities may be planned to coincide with milestones and other capstones within an academic program. William reflected on this issue, noting that "It has to be well-rounded. There has to be opportunities to express yourself in different ways across a degree and learn to relate to the world that you're

\begin{tabular}{|c|c|c|}
\hline Exploring open resources & Openness by design & Open online publishing \\
\hline $\begin{array}{l}\text { Exploring, reviewing, and } \\
\text { curating resources designed } \\
\text { as OER }\end{array}$ & $\begin{array}{l}\text { Resources designed as } \\
\text { OER to be sharing more } \\
\text { widely }\end{array}$ & $\begin{array}{l}\text { Resources presented } \\
\text { on the web for } \\
\text { others to discover }\end{array}$ \\
\hline $\begin{array}{l}\text { Additional considerations: } \\
\text { Awareness of open repositories, } \\
\text { recognition of open licenses, critical } \\
\text { assessment of quality and source }\end{array}$ & $\begin{array}{l}\text { Additional considerations: } \\
\text { Clearing of copyright or use of open } \\
\text { licenses, formatting for web and } \\
\text { considerations around accessibility for } \\
\text { reuse, open licensing }\end{array}$ & $\begin{array}{l}\text { Additional considerations: } \\
\text { Authorship information, addition of } \\
\text { descriptive metadata, publishing in } \\
\text { repository or on web, sharing with } \\
\text { community }\end{array}$ \\
\hline Pedagogical approaches: & Pedagogical approaches: & Pedagogical approaches: \\
\hline $\begin{array}{l}\text { Have learners explicitly seek out, } \\
\text { review, and share OER that might } \\
\text { support their learning } \\
\text { Engage learners with resources in the } \\
\text { public domain or licensed with } \\
\text { Creative Commons } \\
\text { - Be explicit about the use of OER and } \\
\text { the allowances therein }\end{array}$ & $\begin{array}{l}\text { Require learners to use legally } \\
\text { reusable materials in their creations } \\
\text { - Have learners create works that could } \\
\text { be shared as OER } \\
\text { - Require learners to incorporate } \\
\text { accessibility guidelines to ensure their } \\
\text { works are widely accessible } \\
\text { - Encourage learners to license their } \\
\text { works when presented on the web }\end{array}$ & $\begin{array}{l}\text { - Interrogate the concepts of digital } \\
\text { footprint, anonymity, pseudonyms, } \\
\text { and authorships of online works } \\
\text { - Review available repositories for } \\
\text { sharing work and associated metadata } \\
\text { to ensure the work is discoverable } \\
\text { - Engage learners with the creation of } \\
\text { independent portfolios to showcase } \\
\text { their work } \\
\text { - Use social media to promote and } \\
\text { generate feedback and dialogue } \\
\text { around their creations }\end{array}$ \\
\hline
\end{tabular}


going to be stepping into as well." William suggested that he felt assured that his use of OEP was appropriate, as he was confident that learners were doing more traditional assessment tasks in other courses. However, if OEP do become more common practice across the institution, he reflected "if it ever got to that point - I'd say 'okay kids time for a term paper'." This quote suggests an assumption that more traditional teaching and learning approaches default to closed access, while one could argue that a term paper could just as well be shared as an online document, blog post, or multimedia artefact. Again this brings us back to Clark (1994), as it is now possible to share resources from within the same environments in which those resources are created, blurring the lines between design and delivery technologies. This quote also represents an increasingly common assumption that OEP is a combination of open in terms of access and open representing a more flexible inquiry-based pedagogy. This suggests the importance of a delineation of boundaries for terminology so that the semantics around access and pedagogical strategies are clear.

\section{Conclusion}

While a significant amount of research has been conducted to measure the efficacy of OER and open textbooks as learning resources by exploring outcomes and grade point averages, little has been done to measure the impact of openness on learning design and how this impacts the teaching and learning practices of faculty members, as well as the learner experience in being engaged in this way. Like others, we believe researchers should focus on exploring how, and if, openness might stimulate innovation in teaching and learning, to what extent it provides greater autonomy for both learners and educators, how it contributes to the professionalization of teaching, and if it can be used to equip learners with the skills and literacies necessary for engaging in a more open society (Kimmons, 2016; Masterman, 2016). What is perhaps most needed are detailed case studies of OEP, represented through learning designs, traces of which have been contributed as part of this research. Similar to Littlejohn and Hood (2016), this study reinforces the need for longitudinal studies which interrogate how faculty develop and enact OEP learning designs, the specific knowledge artefacts developed therein, and the subsequent impact on student learning.

Increasingly, it would appear that open education is encouraging more faculty to share and collaborate on approaches to teaching and learning using open technologies. Openness has certainly made teaching and learning resources and practices more discoverable, accessible, and reusable, and those affordances have encouraged the sharing and reflection of practice among communities of educators. Gradually, this appears to be resulting in emerging conceptualizations and the ongoing reformation of teaching and learning. As a consequence, participants in this study were discovering and testing out active and engaged pedagogies in their pursuit of openness and in doing so also engaging their learners as open practitioners. This study found evidence that OEP can support a more active role for the learner, develop open/networked literacies, forge pathways to community-engaged learning, and create opportunities for enhanced professional development. We believe this paper contributes some practical ways for faculty members to consider the integration of OEP from a learning design perspective. 
Abbreviations

LMS: Learning management system; OEP: Open educational practices; OER: Open educational resources

\section{Acknowledgements}

The authors would like to thank all of the faculty members who participated in in this study by offering their time, insight, and thoughtful reflections on their practice.

\section{Authors' contributions}

MP conducted the literature review, designed the study, analyzed the results, and prepared the findings. VI provided guidance, review, and feedback throughout all aspects of the study. Both authors read and approved the final manuscript.

\section{Funding}

This research was partially funded by a research grant from BCcampus.

\section{Availability of data and materials}

The a selection of the data generated during the current study which were designated as open data by participants in the study are available in the Scholars Portal Dataverse repository, https://doi.org/10.5683/SP2/CA77BB.

\section{Competing interests}

The authors declare that they have no competing interests.

Received: 3 October 2019 Accepted: 5 December 2019

Published online: 18 December 2019

\section{References}

Aktaruzzaman, M., \& Plunkett, M. (2016). Adapting structuration theory as a comprehensive theory for distance education: The Astide model. European Journal of Open, Distance and E-Learning, 19(1) Retrieved from http://www.eurodl.org/index. php? $\mathrm{p}=$ archives\&year=2016\&halfyear $=1 \&$ article $=713$.

Alevizou, P. (2012). Open to interpretation?: Productive frameworks for understanding audience engagement with OER. In Presented at the Cambridge 2012: Innovation and impact - Openly collaborating to enhance education, a joint meeting of OER12 and OpenCourseWare Consortium Global 2012, Cambridge, UK Retrieved from http://www.ucel.ac.uk/oer12/docs/ Conference_Proceedings_Cambridge_2012.pdf.

Allen, E., \& Seaman, J. (2016). Opening the textbook: Educational resources in U.S. higher education, 2015-16. Retrieved from Babson Survey Research Group website: http://www.onlinelearningsurvey.com/reports/openingthetextbook2016.pdf

Andrade, A., Ehlers, U.-D., Caine, A., Carneiro, R., Conole, G., Kairamo, A.-K., ... Carl Holmberg. (2011). Beyond OER: Shifting focus to open educational practices. Open Educational Quality Initiative.

Banzato, M. (2012). A case study of teachers' open educational practices. Journal of E-Learning and Knowledge Society, 8(3). https://doi.org/10.20368/1971-8829/650.

Bates, T., Desbiens, B., Donovan, T., Martel, E., Mayer, D., Paul, R., ... Seaman, J. (2017). Tracking online and distance education in Canadian universities and colleges: 2017. Retrieved from The National Survey of Online and Distance Education in Canadian Post-Secondary Education website: https://onlinelearningsurveycanada.ca/publications/

Beaven, T. (2013). Use and reuse of OER: Professional conversations with language teachers. Journal of E-Learning and Knowledge Society, 9(1) Retrieved from http://www.je-lks.org/ojs/index.php/Je-LKS_EN/article/view/802.

Beetham, H. (2011). Understanding the role of OERs in open educational practices. Education. Retrieved from http://www. slideshare.net/loumcgill/understanding-the-role-of-oers-in-open-educational-practices

Beetham, H., Falconer, I., McGill, L., \& Littlejohn, A. (2012). Open practices briefing paper. Retrieved from JISC website: https:// oersynth.pbworks.com/w/page/51668352/OpenPracticesBriefing

Bennett, S., Dawson, P., Bearman, M., Molloy, E., \& Boud, D. (2016). How technology shapes assessment design: Findings from a study of university teachers. British Journal of Educational Technology. https://doi.org/10.1111/bjet.12439.

Borthwick, K., \& Gallagher-Brett, A. (2014). 'Inspiration, ideas, encouragement': Teacher development and improved use of technology in language teaching through open educational practice. Computer Assisted Language Learning, 27(2), 163183. https://doi.org/10.1080/09588221.2013.818560.

Bower, M. (2016). Deriving a typology of web 2.0 learning technologies. British Journal of Educational Technology, 47(4), 763777. https://doi.org/10.1111/bjet.12344.

Bulfin, S., Henderson, M., \& Johnson, N. (2013). Examining the use of theory within educational technology and media research. Learning, Media and Technology, 38(3), 337-344. https://doi.org/10.1080/17439884.2013.790315.

Camilleri, A. F., \& Ehlers, U.-D. (2011). Mainstreaming Open Educational Practice: Recommendations for Policy. Retrieved from European Foundation for Quality in E-Learning: The OPAL Consortium website: https://efquel.org/wp-content/uploads/2 012/03/Policy_Support_OEP.pdf.

Camilleri, A. F., Ehlers, U.-D., \& Pawlowski, J. (2014). State of the art review of quality issues related to open educational resources (OER). Luxembourg: European Commission Institute for Prospective Technological Studies.

Carey, T., Davis, A., Ferreras, S., \& Porter, D. (2015). Using open educational practices to support institutional strategic excellence in teaching, learning \& scholarship. Open Praxis, 7(2). https://doi.org/10.5944/openpraxis.7.2.201.

Clark, R. E. (1991). When researchers swim upstream: Reflections on an unpopular argument about learning from media. Educational Technology, 31(2), 34-40.

Clark, R. E. (1994). Media will never influence learning. Educational Technology Research and Development, 42(2), 21-29. https:// doi.org/10.1007/BF02299088.

Corbin, J., \& Strauss, A. (2008). Basics of qualitative research (3rd ed.): Techniques and procedures for developing grounded theory. Thousand Oaks, CA:SAGE Publications, Inc. https://doi.org/10.4135/9781452230153. 
Cox, G. (2016). Explaining the relations between culture, structure and agency in lecturers' contribution and non-contribution to open educational resources in a higher education institution (Doctoral Dissertation, University of Cape Town). Retrieved from https://open.uct.ac.za/handle/11427/20300

Creswell, J. W. (2012). Educational Research: Planning, Conducting, and Evaluating Quantitative and Qualitative Research (4th ed). Boston: Pearson.

Creswell, J. W. (2013). Qualitative Inquiry and Research Design: Choosing Among Five Approaches (3rd ed). Los Angeles: SAGE Publications.

Cronin, C. (2016). Open, networked and connected learning: Bridging the formal/informal learning divide in higher education. In Proceedings of the 10th international conference on networked learning Retrieved from http://www. networkedlearningconference.org.uk/abstracts/pdf/S3_Paper2.pdf.

Cronin, C. (2017). Openness and praxis: Exploring the use of open educational practices in higher education. International Review of Research in Open and Distance Learning, 18(5). https://doi.org/10.19173/irrodl.v18i5.3096.

De Los Arcos, B., Farrow, R., Perryman, L.-A., Pitt, R., \& Weller, M. (2014). OER evidence report 2013-2014. Retrieved from http://oro.open.ac.uk/id/eprint/41866

Deimann, M., \& Farrow, R. (2013). Rethinking OER and their use: Open education as Bildung. The International Review of Research in Open and Distributed Learning, 14(3), 344-360. https://doi.org/10.19173/irrodl.v14i3.1370.

Dron, J. (2016). The classroom-less society: The shifting boundaries of online learning. In 6th annual education technology summit Presented at the Toronto, Canada. Retrieved from https://landing.athabascau.ca/file/view/1580870/the-classroomless-society-slides-from-ed-tech-summit-2016-toronto.

Ehlers, U.-D. (2011). Extending the territory: From open educational resources to open educational practices. Journal of Open Flexible and Distance Learning, 15(2), 1-10.

Ehlers, U.-D. (2013). Open learning cultures: A guide to quality, evaluation, and assessment for future learning. New York, N.Y.: Springer Science \& Business Media.

Friesen, N. (2009). Open educational resources: New possibilities for change and sustainability. The International Review of Research in Open and Distributed Learning, 10(5). https://doi.org/10.19173/irrodl.v10i5.664.

Giddens, A. (1993). New rules of sociological method: A positive critique of interpretative sociologies (2nd ed.). Stanford: Stanford University Press.

Giddens, A., \& Dallmayr, F. R. (1982). Profiles and critiques in social theory. Berkeley: University of California Press.

Giorgi, A. (1997). The Theory, Practice, and Evaluation of the Phenomenological Method as a Qualitative Research Procedure. Journal of Phenomenological Psychology; Leiden, 28(2), 235-260. https://doi.org/10.1163/156916297X00103.

Gray, D. E. (2014). Doing Research in the Real World (3rd ed). London: SAGE.

Halperin, R. (2016). Learning practice and technology: Extending the structurational practice lens to educational technology research. Learning, Media and Technology, 1-16. https://doi.org/10.1080/17439884.2016.1182925.

Harley, D. (2008). Why understanding the use and users of open education matters. In M. S. V. Kumar, T. liyoshi, \& M. S. V. Kumar (Eds.), Opening up education: The collective advancement of education through open technology, open content, and open knowledge (pp. 197-211). Cambridge: MIT Press.

Harris, R. A., \& Higgison, C. A. (2003). Reuse of resources within communities of practice. In A. Littlejohn (Ed.), Reusing online resources: A sustainable approach to e-learning. London; Sterling: Kogan Page.

Hegarty, B. (2015). Attributes of Open Pedagogy: A Model for Using Open Educational Resources. Educational Technology, (July-August 2015), 3-13.

Hein, S. F., \& Austin, W. J. (2001). Empirical and hermeneutic approaches to phenomenological research in psychology: A comparison. Psychological Methods, 6(1), 3-17. https://doi.org/10.1037/1082-989X.6.1.3.

Hodgkinson-Williams, C., \& Gray, E. (2009). Degrees of openness: The emergence of open educational resources at the University of Cape Town. International Journal of Education and Development Using ICT, 5(5), 101-116.

Hood, N., \& Littlejohn, A. (2017). Knowledge typologies for professional learning: Educators' (re) generation of knowledge when learning open educational practice. Educational Technology Research and Development, 1-22. https://doi.org/10. 1007/s11423-017-9536-z

Horsburgh, D. (2003). Evaluation of Qualitative Research. Journal of Clinical Nursing, 12(2), 307-312.

Howard, S., \& Maton, K. (2011). Theorising knowledge practices: A missing piece of the educational technology puzzle. Research in Learning Technology, 19(3), 191-206. https://doi.org/10.1080/21567069.2011.624170.

Kruger, D. (1988). An Introduction to Phenomenological Psychology (2nd ed.). Cape Town, South Africa: Juta Academic

Irvine, V., Code, J., \& Richards, L. (2013). Realigning higher education for the 21st-century learner through multi-access learning. MERLOT Journal of Online Learning and Teaching, 9(2), 15.

Jhangiani, R., Pitt, R., Hendricks, C., Key, J., \& Lalonde, C. (2016). Exploring faculty use of open educational resources at British Columbia Post-Secondary Institutions. Retrieved from https://bccampus.ca/files/2016/01/BCFacultyUseOfOER_ final.pdf

Jung, E., Bauer, C., \& Heaps, A. (2017). Strategic implementation of open educational resources in higher education institutions. Educational Technology, 57(2), 78-84.

Kaatrakoski, H., Littlejohn, A., \& Hood, N. (2017). Learning challenges in higher education: An analysis of contradictions within open educational practice. Higher Education, 74(4), 599-615. https://doi.org/10.1007/s10734-016-0067-z.

Kimmons, R. (2016). Expansive openness in teacher practice. Teachers College Record, 118(Number 9), 1-34.

Knox, J. (2013). Five critiques of the open educational resources movement. Teaching in Higher Education, 18(8), 821-832. https://doi.org/10.1080/13562517.2013.774354.

Koohang, A., \& Harman, K. (2007). Advancing sustainability of open educational resources. Issues in Informing Science and Information Technology, 4, 535-544.

Kozma, R. B. (1994). Will media influence learning? Reframing the debate. Educational Technology Research and Development, 42(2), 7-19. https://doi.org/10.1007/BF02299087.

Lane, A., \& McAndrew, P. (2010). Are open educational resources systematic or systemic change agents for teaching practice? British Journal of Educational Technology, 41(6), 952-962. https://doi.org/10.1111/j.1467-8535.2010.01119.x.

Lane, L. M. (2009). Insidious pedagogy: How course management systems affect teaching. First Monday, 14(10) Retrieved from http://firstmonday.org/ojs/index.php/fm/article/view/2530. 
Littlejohn, A., \& Hood, N. (2016). How educators build knowledge and expand their practice: The case of open education resources: How educators build knowledge and expand their practice. British Journal of Educational Technology, 48(2), 499-510. https://doi.org/10.1111/bjet.12438.

Masterman, E. (2016). Bringing open educational practice to a research-Intensive University: Prospects and challenges. Electronic Journal of E-Learning, 14(1).

Masterman, E., \& Chan, J. (2015). Openness in teaching and learning: An exploration of principles and practices at the University of Oxford [research report]. Retrieved from Academic IT group, IT Services, University of Oxford website: https://weblearn.ox.ac.uk/x/nNvkjt

Masterman, E., \& Wild, J. (2011). JISC open educational resources programme: Phase 2 OER impact study: Research report. University of Oxford Retrieved from http://www.academia.edu/download/26062930/oerimpactstudyresearchreport.pdf.

McAndrew, P., Scanlon, E., \& Clow, D. (2010). An open future for higher education. Educause Quarterly, 33(1) Retrieved from http://www.educause.edu/EDUCAUSE+Quarterly/EDUCAUSEQuarterlyMagazineVolum/ AnOpenFutureforHigherEducation/199388.

McGoldrick, B., Watts, J. S., \& Economou, K. (2015). U.S. Postsecondary Faculty in 2015: Diversity in people, goals and methods, but focused on students. Retrieved from FTI Consulting website: http://postsecondary.gatesfoundation.org/wp-content/ uploads/2015/02/US-Postsecondary-Faculty-in-2015.pdf

Nascimbeni, F., \& Burgos, D. (2016). In search for the open educator: Proposal of a definition and a framework to increase openness adoption among university educators. The International Review of Research in Open and Distributed Learning, 17(6). https://doi.org/10.19173/irrodl.v17i6.2736.

OPAL. (2011). OEP scape: The open educational practice landscape. Essen: ICDE Educational Quality Initiative.

Orlikowski, W. J. (2000). Using technology and constituting structures: A practice lens for studying technology in organizations. Organization Science, 11(4), 404-428. https://doi.org/10.1287/orsc.11.4.404.14600.

Paskevicius, M. (2011). Student perceptions of the reuse of digital educational materials: A case study of the Social Outreach Group SHAWCO (Masters Thesis, University of Cape Town). Retrieved from http://bit.ly/mpaskeviUCT

Paskevicius, M. (2017). Conceptualizing open educational practices through the lens of constructive alignment. Open Praxis, 9(2), 125. https://doi.org/10.5944/openpraxis.9.2.519.

Paskevicius, M., \& Hodgkinson-Williams, C. (2018). Student perceptions of the creation and reuse of digital educational resources in a community development-oriented organisation. Journal of Learning for Development, 5(1) https://j|4d.org/ index.php/ej|4d/article/view/253.

Paskevicius, M., \& Irvine, V. (2019). Open education and learning design: Open pedagogy in praxis. Journal of Interactive Media in Education, 2019(1), 10. https://doi.org/10.5334/jime.512.

Petrides, L., Jimes, C., Middleton-Detzner, C., \& Howell, H. (2010). OER as a model for enhanced teaching and learning. Open ED 2010 proceedings. Presented at the Barcelona, Spain. Retrieved from http://hdl.handle.net/10609/4995

Petrides, L., Jimes, C., Middleton-Detzner, C., Walling, J., \& Weiss, S. (2011). Open textbook adoption and use: Implications for teachers and learners. Open Learning, 26(1), 39-49. https://doi.org/10.1080/02680513.2011.538563.

Pitt, R. (2015). Mainstreaming open textbooks: Educator perspectives on the impact of OpenStax college open textbooks. The International Review of Research in Open and Distributed Learning, 16(4). https://doi.org/10.19173/irrodl.v16i4.2381.

Porter, D. A. (2013). Exploring the practices of educators using open educational resources (OER) in the British Columbia higher education system (Doctoral Dissertation, Simon Fraser University). Retrieved from http://summit.sfu.ca/item/13663

Pulker, H., \& Calvi, A. (2013). The evaluation and re-use of open educational resources in language teaching - A case study. In Presented at the OER13: Creating a virtuous circle, Nottingham, UK Retrieved from http://oro.open.ac.uk/38056/.

Rolfe, V. (2017). Striving toward openness: But what do we really mean? The International Review of Research in Open and Distributed Learning, 18(7). https://doi.org/10.19173/irrodl.v18i7.3207.

Stagg, A. (2014). OER adoption: A continuum for practice. RUSC. Universities and Knowledge Society Journal, 11(3), 151. https:// doi.org/10.7238/rusc.v11i3.2102.

Stagg, A. (2017). The ecology of the open practitioner: A conceptual framework for open research. Open Praxis, 9(4), 363-374.

The Cape Town Open Education Declaration. (2007). Cape Town, South Africa. Retrieved from http://www. capetowndeclaration.org/.

Tosato, P., \& Bodi, G. (2011). Collaborative environments to foster creativity, reuse and sharing of OER. European Journal of Open, Distance and E-Learning, 14(2) Retrieved from http://www.eurodl.org/? p=special\&sp= articles\&article $=461$ \&abstract $=456$.

van Mourik Broekman, P., Hall, G., Byfield, T., Hides, S., \& Worthington, S. (2014). Open education: A study in disruption. London; New York: Rowman \& Littlefield International.

Veletsianos, G. (2015). A case study of scholars' open and sharing practices. Open Praxis, 7(3), 199-209. https://doi.org/10. 5944/openpraxis.7.3.206.

Weller, M., de los Arcos, B., Farrow, R., Pitt, B., \& McAndrew, P. (2015). The impact of OER on teaching and learning practice. Open Praxis, 7(4). https://doi.org/10.5944/openpraxis.7.4.227.

Wiley, D. (2017). OER-enabled pedagogy. Retrieved 3 May 2017, from iterating toward openness website: https:// opencontent.org/blog/archives/5009

Wiley, D., \& Hilton III, J. L. (2018). Defining OER-enabled pedagogy. The International Review of Research in Open and Distributed Learning, 19(4). https://doi.org/10.19173/irrodl.v19i4.3601.

Yuan, L., MacNeill, S., \& Kraan, W. G. (2008). Open educational resources-Opportunities and challenges for higher education. Retrieved from JISC CETIS website: http://wiki.cetis.ac.uk/images/O/Ob/OER_Briefing_Paper.pdf

\section{Publisher's Note}

Springer Nature remains neutral with regard to jurisdictional claims in published maps and institutional affiliations. 